\title{
Environmental performance of the urban microclimate in pedestrian zones of Tarija, Bolivia
}

\begin{abstract}
One of the main challenges facing the city is the need to improve the conditions of urban mobility and accessibility as fundamental aspects of urban life with social, spatial, functional, and cultural repercussions for adaptation to climate change. For this purpose, analysing thermal comfort and the influence of microclimate as the main factors of determining urban heat islands (UHI) caused by solar radiation from construction materials and surfaces leads to the following research question: How do pedestrian zones affect the microclimate and how can they contribute to thermal comfort? The objective of this article is to evaluate the environmental performance of the urban microclimate in a single street in the historic centre of the city of Tarija. The method consists of applying a simulation with the ENVI-met 4.4.5 software to two scenarios: 1) asphalt road and parking areas, and 2) pedestrian path with vegetation and natural surface materials. The simulated maps present variables of air temperature, $\mathrm{T}$ surface, and radiant temperature to determine the level of thermal comfort calculated with the predicted mean vote index (V). The results showed a $6{ }^{\circ} \mathrm{C}$ difference in the surface temperature between both scenarios, and the PMV index was comfortable at 9:00, while later, at $12 \mathrm{~h}$ and $15 \mathrm{~h}$, the index improved with the incorporation of vegetation and natural materials on the road surface. Similarly, through remote sensing, $5.14{ }^{\circ} \mathrm{C}$ was obtained as the land surface temperature (LST). These indicators spotlight the effects of the change in the urban microclimate to improved decision-making in urban design and argue for a network of pedestrian areas in the city.
\end{abstract}

Keywords: microclimate, ENVI-met simulation, pedestrian streets, Tarija (Bolivia)

\section{Introduction}

Pedestrian environments in cities chiefly favour accessibility and walkability; however, they also have an impact on the urban landscape and urban microclimate. The term accessibility relates to the idea of ability to access a particular service or activity, and is measured with distance or time. On the other hand, walkability focuses more on the sensorial experience of space. Walkability can be understood as one of many components of the entire idea of accessibility and vice versa (Juvančič \& Žnidaršič, 2020). Walkability is beneficial to human beings in many ways. Within the social aspect, walking is a sustainable mode of travel that protects the environment both for present-day inhabitants and future generations. Walking has positive effects on both physical and mental health: locomotion leads to healthier bodies; exposure to the physical and social environment leads to healthier minds; reduced automobility means reduced risk of dangerous traffic collisions and reduced harm from air pollution. Each of these benefits is especially important to babies and toddlers, who are particularly sensitive to air pollution (Internet 1).

When people perceive an active public space with a functional aspect, they develop their activities around a new range of opportunities and resources offered by the city; even more so when there is an opportunity for local tourism in the historic centre with its architectural heritage and cultural value that creates attractive routes and ensures the permanent presence of pedestrians. Making downtown into a walkable, viable community is the essential fix for the typical American city; it is eminently achievable and its benefits are manifold (Speck, 2012). Considering other land uses in open spaces - which, according to Gehl (2006), is where the 
character of activities between people is defined - three types can be identified: necessary, optional, and social. The planning or design phase of an urban project, as indicated by the TOD Standard (Internet 1), comprised of eight principles, should take into consideration walking (safe, complete, and accessible pedestrian network for all, an active and vibrant pedestrian environment, a warm and comfortable pedestrian environment), connecting (short, direct, and varied pedestrian routes), and changing (space occupied by cars reduced to a minimum).

In terms of both climate and local air quality, walking has a lesser environmental impact than any other mode of transportation. The spatial aspect and the microclimatic factors in the environment can affect human health and well-being. According to Oke (1987), the influence of urbanization on climate creates urban heat islands (UHI), where the difference in climate conditions recorded by an observer in the urban area of the city, compared to one in the rural environment, is determined by its thermal balance and can reach up to $10{ }^{\circ} \mathrm{C}$ (Tumini, 2012). There are manifold factors of anthropogenic origin contributing to the creation of UHIs: maintaining impermeable surfaces; finishing materials in buildings; geometry of urban canyons; cars, air pollution, and CO2 emissions; traffic and metabolism of living organisms; and soil cover. In order to understand these differences, the present article presents a microclimatic simulation of a potential pedestrian environment, comparing the results of temperature (radiant, surface, and air temperature) with the PMV comfort indicator.

There are more than one hundred neighbourhoods in the city of Tarija, some of them of recent creation and in urgent need of a re-think of an urban planning mechanism that would ensure the quality of life, since, according to Jacobs (2011), the relationship of people with public space as a social connector is a key issue of the city. It is even more urgent nowadays in order to combat the fragmentation that is one of the legacies bequeathed to the cities by the current health crisis. In their discussion of the concept of "chrono-urbanism" as a way to improve the quality of life in cities in regard to space and time with the introduction of the "15-minute city", Moreno et al. (2021) propose creation of walkable neighbourhoods that would increase social cohesion and interaction, and contribute to sustainable ecosystems in cities with the introduction of more biking and walkable streets, and thus also help combat the challenges of private car ownership. Meanwhile, Sweden's plans to arrive at net zero greenhouse gas emissions by 2045 are implementing a pilot project of transforming single blocks in order to redesign space with a vision of one-minute city (Peters, 2021).

As pointed out by Moreno et al. (2021), streets should be more optimized towards the needs of humans and nature. Present-day streets are mainly designed for cars, leaving little or no space for other activities. Such a situation is not sustainable. One of the main goals in the cities consists of increasing the number and area of pedestrian zones as a way of adapting to climate change and improving urban comfort and health. Therefore it is necessary to understand their environmental performance. The morphological perception of urban tissue and intraurban landscape correlated, under quality perspective, with urban findings such as the land use, urban infrastructure, and environmental balance assessments offers a safe way to classify the urban quality of a territorial fraction (Romero et al., 2019).

In order to study this effect on the physical consolidation and growth of the city, it is necessary to define a scale for future interventions, and analytical real-life and alternative scenarios. Different authors have arrived at different classifications regarding built structures, surfaces, and human activities. Stewart \& Oke (2012) propose an urban climate classification in which the urban landscape is ordered into structures with similar properties related to the types of construction and land cover, called local climate zones; this method is then organized in 
technical data sheets. The characteristics of the elements that make up urban landscapes, such as sky view factor, height and width of urban canyons, roughness, fraction of the built surface, fraction of the impermeable surface of the soil, and proportion of the permeable area of the soil, are among the characteristics that can be adapted according to the specificity of an urban climate study.

Classification of spatial scales is defined by each particular context: city, district, neighbourhood, and block. The city is defined by its geographic distribution, maps of communication routes, public transport, and location of energy consumption centres. The district is marked by the complexity and connectivity of street networks, diversity in house sizes and prices, different activities, and land use mix. On this level, the walkable distance is estimated as 1,500 m (or c. 1 mile in the North American context). Next, the neighbourhood is characterized by the morphology of physical phenomena within the urban fabric. Physical parameters are influenced by the shape of the streets (urban canyons of $h / 1$ ratio), while another important factor on this scale is segregation by proximity parameters. The walkable distance is estimated as 400m (or c. 1/4 mile in the North American context). Finally, the block contains the morphological parameters and urban configurations of adjacent or homogeneous buildings. Of importance for thermal calculations are connectivity and proximity, as referenced by Moreno et al. (2021), as well as distribution indicators such as diversity and morphology. In a highly versatile block, the built part is framed by the streets and buildings. According to Salat et al. (2011), the spatial measurement systems for formal or typological choice, and their implications for energy, should not be used as absolute values but as a means of evaluating relative performance while comparing different types of forms, neighbourhoods, or cities. Since the present article compares two scenarios, the analysis is based on this classification overlapping the categories that emphasize the main themes of the spatial scales considering land use, mobility, water management, biodiversity, energy, equity, economy, well-being, waste and materials, energy and bioclimatism. The themes proposed by the author overlap the seven analysis grids with a subdivision of the indicator, resulting in: 1) intensity, articulated with regard to the concentration of people or density of habitations; 2) diversity with a mix of diverse but similar objects on a certain scale; 3) proximity, regarding the distance required to reach certain activities, places of work, and nodes of public transport; 4) complexity, being a vital feature of sustainable urban places and energy efficiency; 5) connectivity, regarding accessibility and spatial interconnection of systems and networks; 6) distribution, considering population concentration or density of residential buildings; and 7) form, referring to the spatial form of the elements, their dimensions and footprint (Salat et al., 2011: 485).

After the global health crisis caused by the Covid19 pandemic, the great challenges that presentday cities face are fundamentally expressed in guaranteeing - in a sustainable way- an adequate use and occupation of land, adapting development to the demand for new relationships with the environment, which presupposes an adequate understanding of the place. Consequentially, there is a growing need for synergy between technique, governance, and culture (Martínez \& Bustos, 2020). It implies walkable neighbourhoods with reachable provision and amenities, and a healthy lifestyle (Moreno et al., 2021). There is an urgent need to change the unsustainable practices, since the creation of urban environments accommodating cars has prompted the demand for vehicular-dependent cities, associated with mass production, industrialization, oil dependency, social inequalities, and worsening effects of climate change.

This paper is composed of three sections: firstly, a characterization of climate in Tarija on a typical warm day in 2019; secondly, applying the method to capture the UHI comparison with 
microsimulation and LST above the historical street with two scenarios (an actual and an alternative one); and, finally, the discussion of the results.

\section{Methods}

This research, inductive in nature, is composed of two modelling phases and two previous procedures to characterize the local climate and to define the scenarios. Firstly, the method includes a specific and precise analysis on the 15 de Abril Street in Tarija, Bolivia. The vehicular road has the following surface characteristics: asphalt road and concrete grey pavement / sandy soil in the two vehicular garages on the block ). The cut-out in the historical centre of the city articulates two squares (the main square Luis de Fuentes and Plazuela Sucre), while the pavements were widened in 2014 (Figure 1).

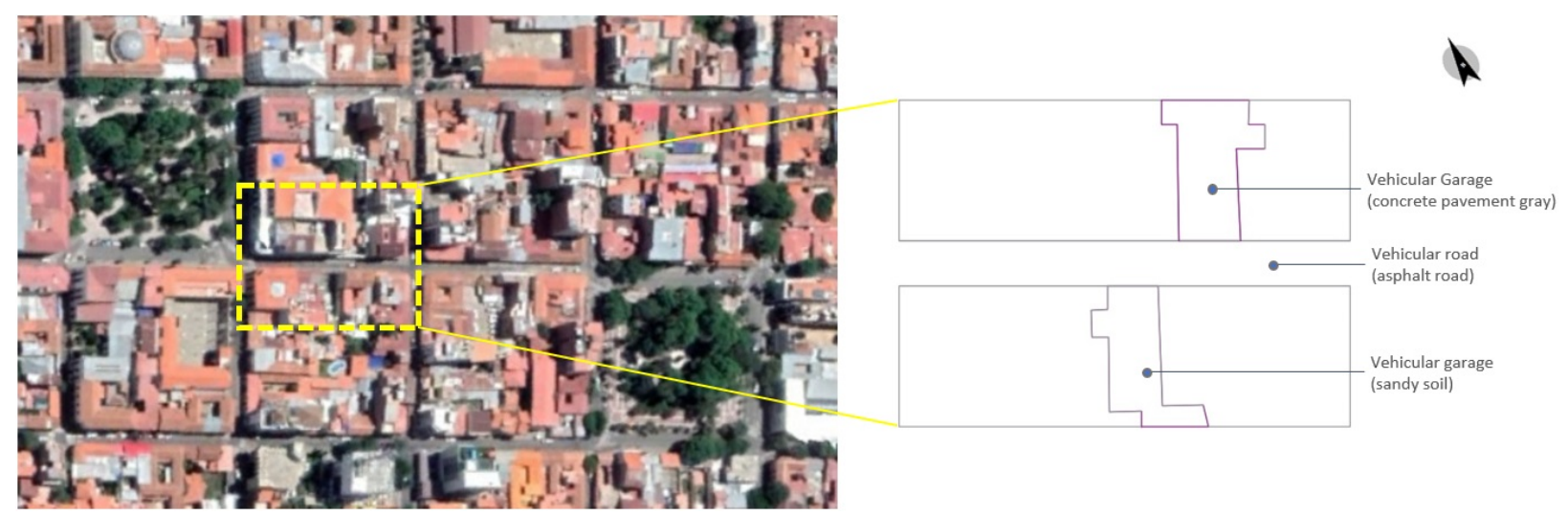

Figure 1: Cut-out of the case study - territorial fraction (source: Google Earth Pro, 2020; adapted by the author).

Secondly, the research applies remote sensing to review Land Surface Temperature (LST) in order to identify centralities in neighbourhoods as an alternative pedestrian circuit. Regarding the scale, the place can be classified into three types of neighbourhoods: the historical centre (with architectural and cultural heritage), the conventional neighbourhoods, and the new settlement (with temporary informal occupations). Note the extension to the rural area (Figure 2). 


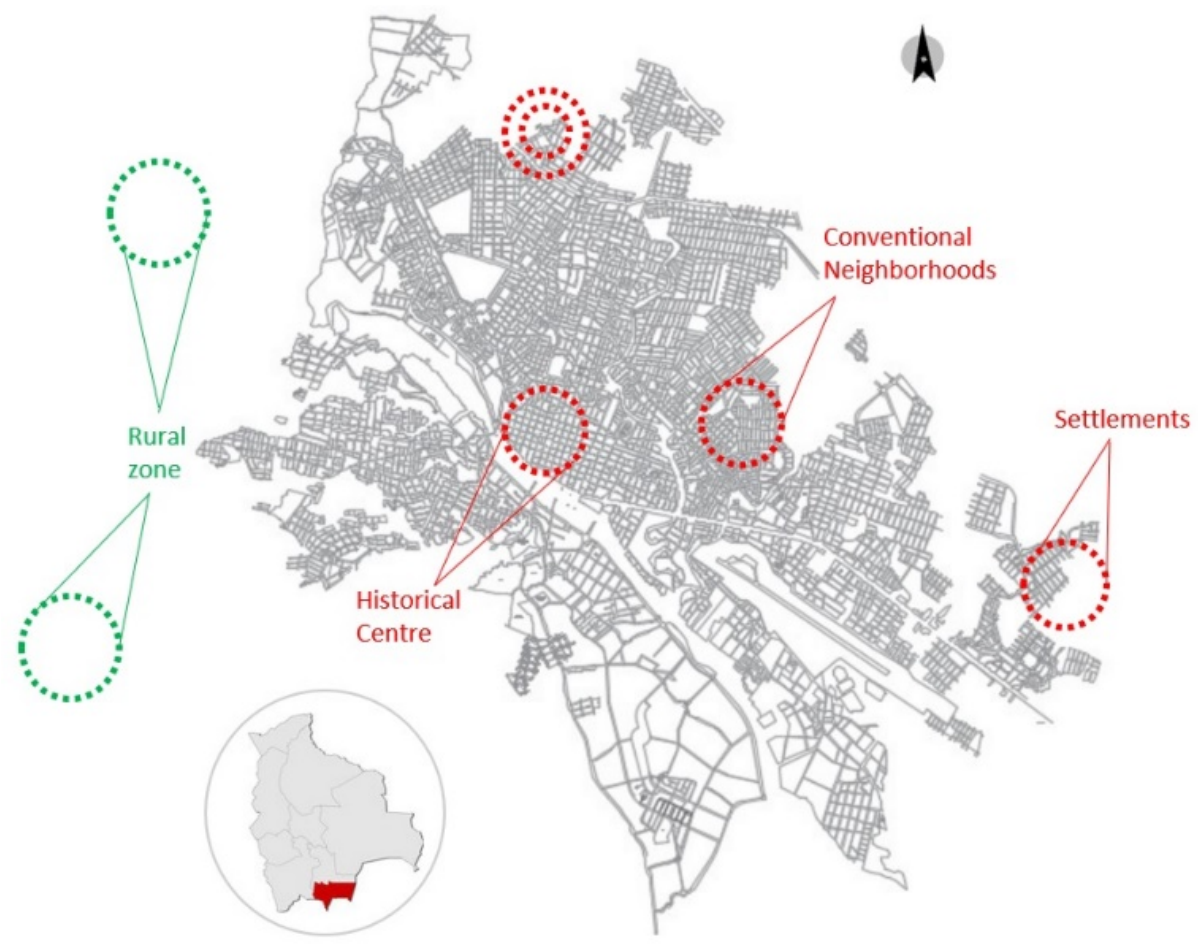

Figure 2: Urban area of Tarija (illustration: author).

In order to qualify an urban space, Romero (2011) proposes a set of urban climate scales and, additionally, a formula to determine the interaction of the elements: urban + architectural + environmental + inhabitants of the place. On this basis, it is possible to verify the relationship that exists between urban geometry and environmental factors of climate. The present research focuses on environmental performance factors through urban microclimate.

\subsection{Characterization of the climate in Tarija}

The city of Tarija is located in southern Bolivia at $21^{\circ} 32^{\prime} 07^{\prime \prime}$ S latitude and $64^{\circ} 43^{\prime} 46^{\prime \prime} \mathrm{W}$ longitude and at $1875 \mathrm{~m}$ asl. According to the Köppen-Geiger climate classification, its climate corresponds to BSk (cold semi-arid climate), subtype Cwb (oceanic subtropical highland climate). Data from the Bolivian meteorological database SISMET (Meteorological Data Processing System) shows the average maximum temperature in Tarija in the historical record 1962-2017 reaching $31.8^{\circ} \mathrm{C}$ for the month of November 2009 (Tarija Airport weather station). The average annual temperature was $17.7^{\circ} \mathrm{C}$; however, in the same month of November 2009 it reached $24{ }^{\circ} \mathrm{C}$, followed by $23.6^{\circ} \mathrm{C}$ in December 2012. The average minimum temperature was $15{ }^{\circ} \mathrm{C}$ and the average maximum temperature $25{ }^{\circ} \mathrm{C}$, making December 7, 2019 the warmest day. The relative humidity varies on average between $45 \%$ and $70 \%$. The average wind speed is $1.6 \mathrm{~km} / \mathrm{h}$, predominantly blowing from the east. The average rainfall consists of $556 \mathrm{~mm}$. Due to its temperate climate, Tarija is an important centre of production of wines and spirits with the designation of origin (for instance, the world-famous Singani brandy). During the summer season (between December and March), high-altitude vineyards, located at 2,100 $\mathrm{m}$ asl, attract a large number of tourists to the city (mainly from neighbouring Argentina).

\subsection{Definition of scenarios}

Two different scenarios were applied in the street with different surface materials, and with 8$\mathrm{m}$ wide and 8-m high buildings (Figure 3). 
- Scenario 1: asphalt on the vehicular road and granite pavement on the sidewalks. Road profile: total width of $8 \mathrm{~m}$, with $6 \mathrm{~m}$ of asphalt (space for parking, and space for traffic and vehicular circulation) and $1 \mathrm{~m}$ of pavement on each sidewalk (actual situation).

- Scenario 2: granite pavement only (block pavers), with total width of $8 \mathrm{~m}$ and incorporated vegetation (5 lapacho trees) to convert the street into pedestrian and cycling zone (alternative solution).

For the present purpose, pedestrian walkability was assessed on the basis of TOD standards considering accessibility of 10 - and 20-min walks at an average speed of $3 \mathrm{~km} / \mathrm{h}$. Each scenario was modelled by defining environmental parameters, material physical properties, and boundary conditions in ENVI-met (Table 1). This is characteristic of most of the streets (tertiary routes in the neighbourhoods) in the city (scenario 1), while the road profile varies up to $70 \mathrm{~m}$ on the principal avenue (three lanes with planters).
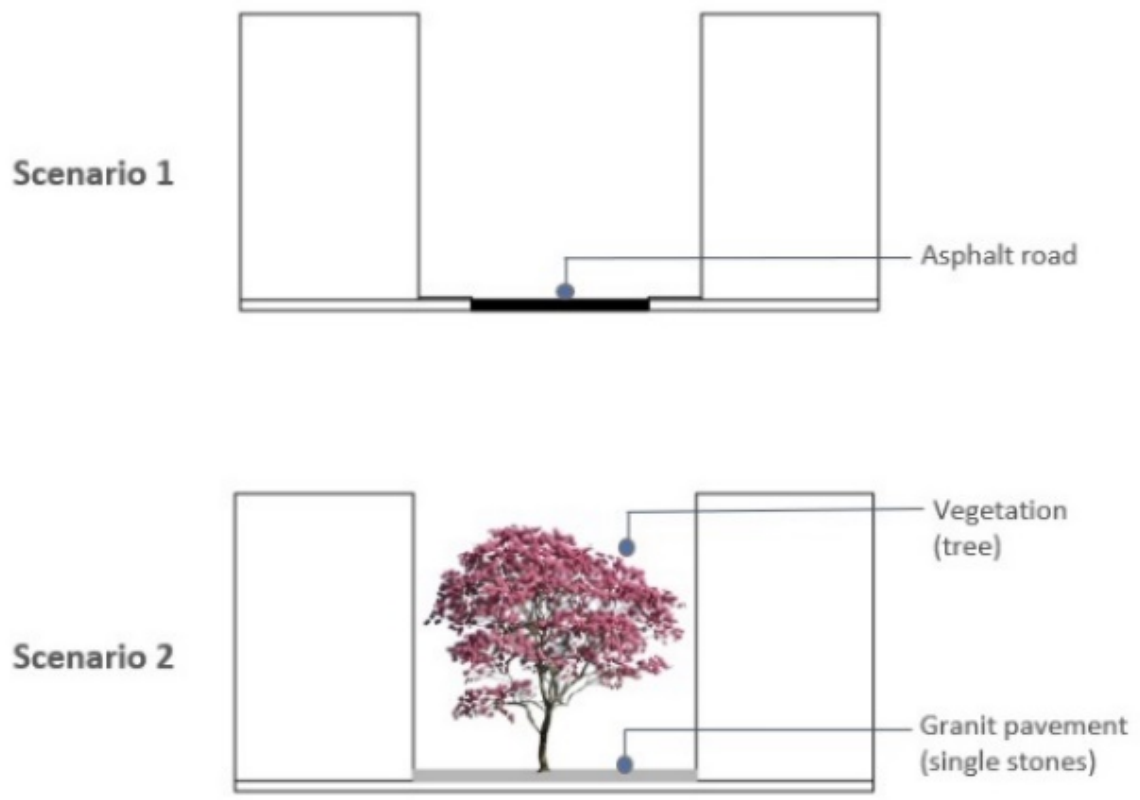

Figure 3: Simulation scenarios (illustration: author).

\subsection{Simulation ENVI-met 4.4.5}

ENVI-met is a "holistic computational model based on thermo-fluid dynamic principles that evaluates fluid-dynamic and thermodynamic interactions between the atmosphere, plants, surfaces, and urban contexts" (Marrone \& Orsini, 2018: 350) in order to estimate microclimatic performance. The three-dimensional urban microclimate model includes the simulation of flooding around and between buildings, exchange of heat and steam processes on the ground surfaces and walls, turbulence, vegetation exchange and vegetation parameters, bioclimatology, and particle dispersion (Bruse, 2004). The results show climate change in a given sector and provide a critical observation in order to propose bioclimatic strategies that would improve the characteristics in different scenarios.

The method includes five procedures: data collection (crop and climate archive), modelling and simulation (both in Envi-met), map extraction (Leonardo plugin), and finally analysis and discussion of results. Table 1 contains the calibration parameter. 
Table 1: Values used to define the model's boundary conditions.

\begin{tabular}{ll}
\hline Variable & Parameter \\
\hline Grid size & $80 * 80 * 60$ \\
Simulation date & 07 December 2019 \\
Total Simulation Time & $24 \mathrm{~h}$ \\
Start Time & 07.00 .00 \\
Wind speed (m/s) & 1.50 \\
Wind direction (deg) & 90.00 \\
Roughness length & 0.010 \\
Temperature of atmosphere & $22(\min ) 34$ (max) \\
T $\left({ }^{\circ} \mathrm{C}\right)$ & \\
Humidity q (\%) & 50 (min) 70 (max) \\
\hline
\end{tabular}

Source: adapted from ENVI-met (2020).

The ENVI-met model, which is able to simulate microscale interactions between urban surfaces, vegetation, and the atmosphere, allows to analyse the effects of small-scale changes in urban design (trees, backyard greening, new building constellations) on microclimate under different mesoscale conditions (Bruse \& Fleer, 1998). The environmental variables for this case study are as follows:

a) Air temperature - the AT value is strongly influenced by irradiance conditions (RS) and surface temperature (ST) (Marrone \& Orsini, 2018).

b) Surface temperature - the ST value varies with the direct or screened irradiance conditions (RS) and the type of material (material albedo and thermal conductivity), (Marrone \& Orsini, 2018).

c) Median radiant temperature $\left(\mathrm{Tmrt}{ }^{\circ} \mathrm{C}\right)$ - one of the main factors of influence on the outdoor thermal comfort level; it is affected by the total amount of radiation absorbed by the human body and is directly affected by urban morphology, street canyons, wind speeds, building facades, and surface materials (Yilmaz et al, 2020).

d) Predicted mean vote (PMV) - thermal comfort index is calculated on the basis of personal factors (metabolic rate [met] and clothing insulation [clo]) and environmental factors (air temperature [Ta], radiant temperature [Tmrt], air velocity, and relative humidity) (Soelaiman et al., 2018). The scale based on Fanger's (1972) thermal comfort model ranges from Cold (-3) to Hot (3), while it is regarded as thermally comfortable between -0.5 and 0.5. PMV index with seven scales is used to measure thermal comfort level (Table 2). According to the ASHRAE Standard 55, thermal comfort is the condition of mind that expresses satisfaction with the thermal environment.

Table 2: PMV index scales with thermal perception.

\begin{tabular}{cl}
\hline Scales & Thermal perception \\
\hline-3 & Cold \\
-2 & Cool \\
-1 & Slightly cool \\
0 & Comfortable/Neutral \\
1 & Slightly warm \\
2 & Warm \\
3 & Hot \\
\hline
\end{tabular}

Source: adapted from Dyvia \& Arif (2020).

The PMV has been criticized for overestimating warm/cold discomforts with errors larger than one scale, which results in overcooling/overheating, thereby thermal discomfort and energy wastage. In fact, available climate models are effective in predicting global temperature changes associated with greenhouse gases, with most models forecasting increases above $3{ }^{\circ} \mathrm{C}$ (Lombardo, 2004). 


\subsection{Land surface temperature (LST)}

According to Baptista (2021), the MOD11A2 product provides an average 8-day land surface temperature (LST) on a $1200 \times 1200$ kilometre grid. Each pixel value in MOD11A2 is a simple average of all the corresponding MOD11A1 LST pixels collected within that 8-day period. The 8-day period compositing period was chosen because twice that period is the exact ground track repeat period of the Terra and Aqua platforms. Along with both the day-and night- time surface temperature bands and their quality indicator (QC) layer, this tool also includes MODIS bands 31 and 32 and eight observation layers (https://developers.google.com/earthengine/datasets/catalog/MODIS_006_MOD11A2).

LST is a key parameter in the physics of land surface processes from local to global scales. LST data is acquired using thermal remote sensing by the Terra (MOD) and Aqua (MYD) satellites with the MODIS sensor on board (Morin et al., 2021) (elevation data in Table 3). The MODIS thermal satellite imagery was acquired through the code editor of Google Earth Engine (Figure 4). Mapping system with moderate resolution allows for two innovations: firstly, the tool using MODIS11A2 to measure LST for $1 \mathrm{~km}$ in an 8-day period creates an image of surface temperature with $1 \mathrm{~km}$ of spatial resolution for each pixel; secondly, it provides both day- and night-time data, and thus allows for comparison of the phenomena of day and night heat islands, proving that they were maintained in both periods (Baptista, 2003). Thermal remote sensing data with high temporal resolution is an interesting alternative for identifying comparable spatial distribution of air temperature or LST.

Table 3: Overview of dataset.

\begin{tabular}{lccc}
\hline Product and source & $\begin{array}{c}\text { Spatial } \\
\text { resolution }\end{array}$ & $\begin{array}{c}\text { Temporal } \\
\text { resolution }\end{array}$ & Variable \\
\hline MOD11A2/MYD11A2 & $1000 \mathrm{~m}$ & $\begin{array}{c}\text { 8-day } \\
\text { composite }\end{array}$ & $\begin{array}{c}\text { Minimum and maximum land } \\
\text { surface temperature }\left({ }^{\circ} \mathrm{C}\right)\end{array}$ \\
\hline
\end{tabular}

Source: adapted from Morin et al. (2021).

To obtain surface temperature, the following procedure is applied to the code editor of Google Earth Engine (Baptista, 2021) First, choose the script MODIS_006 (version 6) product MOD11A2. Make a change in the time filter for the year 2019 (the same year evaluated with ENVI-met), present a resolution of $1 \mathrm{~km}$ (LST_Day_1 km) and a change of 64\%43'46” in longitude and $21^{\circ} 32^{\prime} 07^{\prime \prime}$ in latitude corresponding to the city of Tarija. When processing the dataset centre, a sinusoidal projection appears with the following information obtained in the Inspector tab: 46 images to compose the data in 2019, 1 band, the temperature data, and the resolution of the pixel/km data. For this research, 5 points have been considered (Figure 2), corresponding to the 3 types of neighbourhoods (in the historic centre, conventional neighbourhoods, and new settlements). Additionally, the temperatures in the rural area and the hottest pixel are presented in Figure 4. The result of the radiometric temperature in Table 4 was converted to degrees Celsius. There is a thermal gradient and the LST maximum is $46.85^{\circ} \mathrm{C}$.

Table 4: Land surface temperature - thermal gradient.

\begin{tabular}{lcc}
\hline \multicolumn{1}{c}{ Location } & Pixel/km & LST \\
Rural area & 14942 & $25.69^{\circ} \mathrm{C}$ \\
Hottest (Los Chapacos) & 15539 & $37.63^{\circ} \mathrm{C}$ \\
Historical centre & 15439 & $35.63^{\circ} \mathrm{C}$ \\
Conventional neighbourhood & 15282 & $32.49^{\circ} \mathrm{C}$ \\
Settlement & 15283 & $34.51^{\circ} \mathrm{C}$ \\
\hline
\end{tabular}

Source: author (2021). 

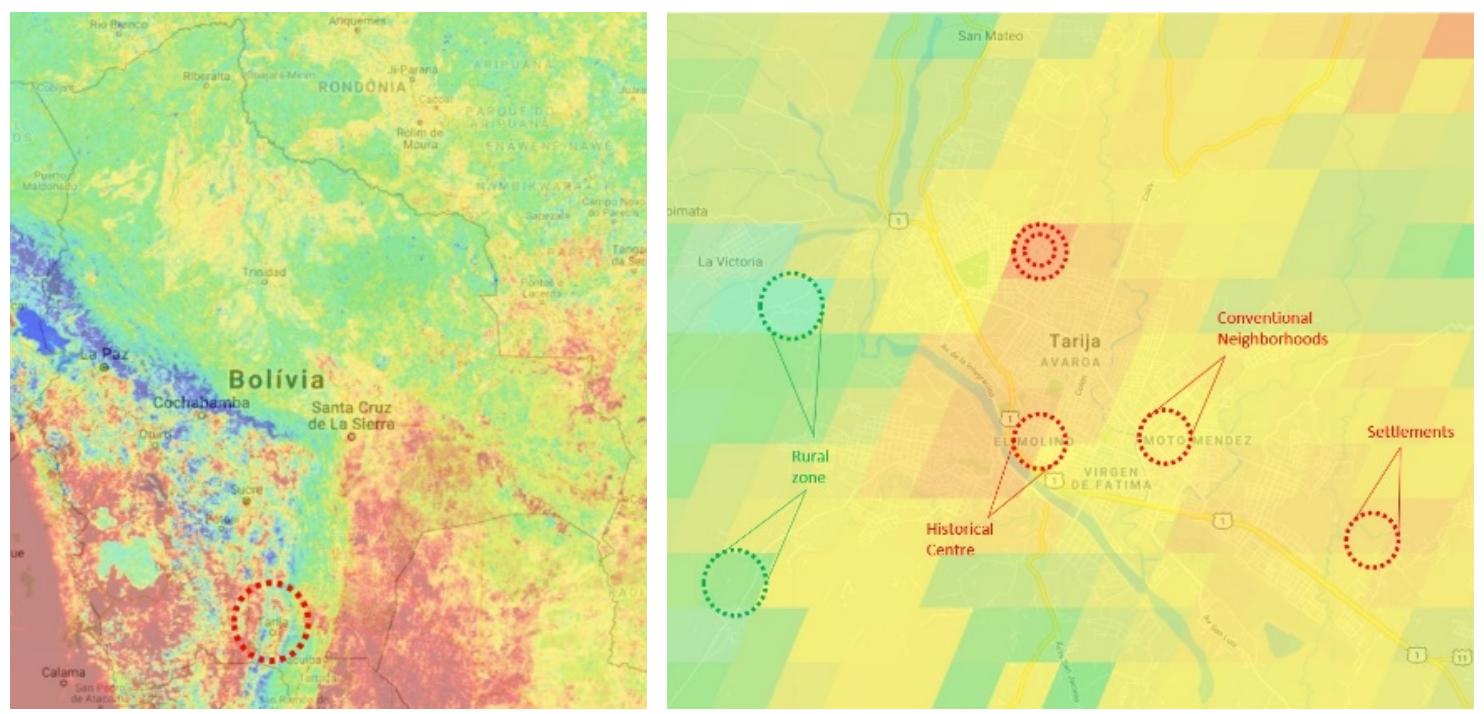

Figure 4: LST of Bolivia, Tarija (source: MODIS11A2 - Google Earth Engine, 2021).

Several studies have demonstrated the utility of methods for "downscaling” land surface temperature (LST) derived at low spatial resolutions from remote sensing to improve the precision of these data by using robust statistical methods and predictors (Morin et al., 2021). Such "downscaling" is related to reducing pollution and stress, and creating socially and economically mixed districts, in order to improve overall quality of life for both residents and visitors.

\section{Results}

Comparing LST measurements, a $11,94^{\circ} \mathrm{C}$ difference between urban area with rural area was arrived at. Additionally a $5.14^{\circ} \mathrm{C}$ difference between the three types of neighbourhoods within the urban area (historical centre, conventional neighbourhoods, and new settlements) was observed (Table 4). These results on a macro scale (thinking at the city level) give a guideline to the results obtained with the simulation, as developed below. The results of the simulation with three parameters (air temperature, temperature surface, and median radiant temperature) at five different hours $(9: 00,12: 00,15: 00,18: 00$, and 21:00) for each scenario are shown in Figures 5, 6, and 7. Meanwhile, the last chart (Figure 8) compares scenarios 1 and 2 with the PMV index. All maps extracted by Leonardo are standardized.

As pointed out by Bruse (2004), a wide range of different soil and surface types is characteristic of urban environments, varying from natural soils to completely artificial materials. For this reason, values in both scenarios should be standardized in order to compare observed data in the maps of surface temperature, median radiant temperature, and PMV. The maps for the four environmental parameters (air temperature, surface temperature, median radiant temperature, and PMV) resulting from the simulation, and considered at $1.5 \mathrm{~m}$ reference height, according to the rules of the World Meteorological Organization, show the differences in both scenarios at 9:00, 12:00, 15:00, 18:00, and 21:00.

\subsection{Scenario 1: asphalt street and parking areas (actual situation):}

- Air temperature reached between $18{ }^{\circ} \mathrm{C}$ and $25^{\circ} \mathrm{C}$. The minimum value was reached at 9:00 and the highest value at 15:00 (Figure 5). 
- T surface reached between $21^{\circ} \mathrm{C}$ and $29^{\circ} \mathrm{C}$. At 12:00 and 15:00 the worst performance was recorded even in the vehicular garages. The more comfortable performance was recorded at 21:00 (Figure 6).

- Median radiant temperature reached between $22.5^{\circ} \mathrm{C}$ and $42.50{ }^{\circ} \mathrm{C}$. The minimum value was registered at 21:00 and the highest value (over $42^{\circ} \mathrm{C}$ ) at 15:00 (Figure 7).

According to the three environmental factors / bioclimatic parameters represented, the worst performance in this scenario was recorded at 15:00 .

\subsection{Scenario 2: street with block pavers and vegetation (alternative solution):}

- Air temperature reached between $18{ }^{\circ} \mathrm{C}$ and $23{ }^{\circ} \mathrm{C}$. The minimum value was registered at 9:00 and the highest value at 15:00 (Figure 5).

- T surface reached between $21^{\circ} \mathrm{C}$ and $29{ }^{\circ} \mathrm{C}$. The worst performance was recorded at 15:00, with slightly higher temperatures than at 12:00. The more comfortable performance was recorded at 9:00 (Figure 6).

- Median radiant temperature reached between $22.5^{\circ} \mathrm{C}$ and $42.50{ }^{\circ} \mathrm{C}$, with the minimum value registered at 18:00 and 21:00, while at $15: 00$ the temperature reached around $30^{\circ} \mathrm{C}$ (Figure 7). Compared to scenario 1 , this result registered a decrease of about $12^{\circ} \mathrm{C}$ at $15: 00$. Additionally, the minimum value was recorded at both 18:00 and 21:00 in scenario 2. The following three maps show the distribution of temperature from scenarios 1 and 2, obtained from ENVI-met 4.4.5.

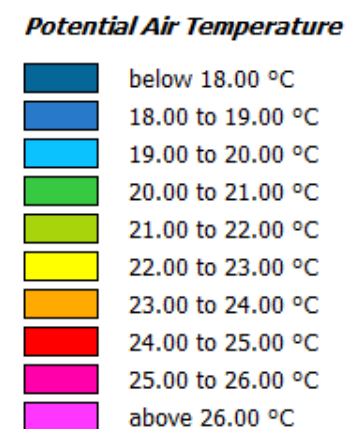

9:00

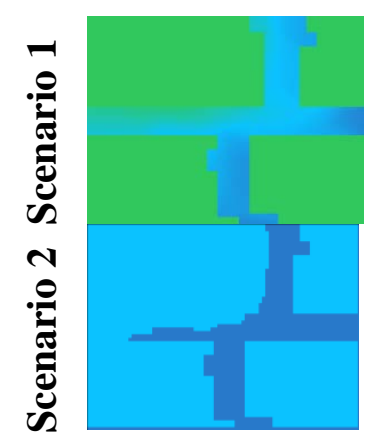

12:00

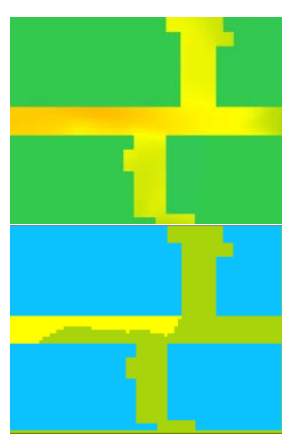

15:00

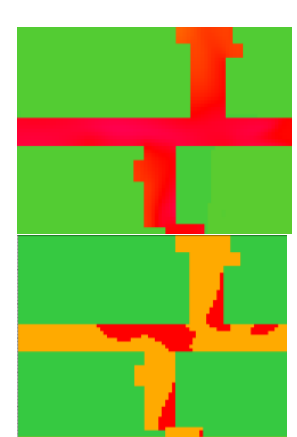

Figure 5: Map of Air Temperature (illustration: Leonardo plugin, 2020).
18:00

21:00 


\section{TSurface}

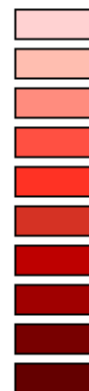

below $21.00^{\circ} \mathrm{C}$

21.00 to $22.00^{\circ} \mathrm{C}$

22.00 to $23.00^{\circ} \mathrm{C}$

23.00 to $24.00^{\circ} \mathrm{C}$

24.00 to $25.00^{\circ} \mathrm{C}$

25.00 to $26.00^{\circ} \mathrm{C}$

26.00 to $27.00^{\circ} \mathrm{C}$

27.00 to $28.00^{\circ} \mathrm{C}$

28.00 to $29.00^{\circ} \mathrm{C}$

above $29.00^{\circ} \mathrm{C}$

9:00

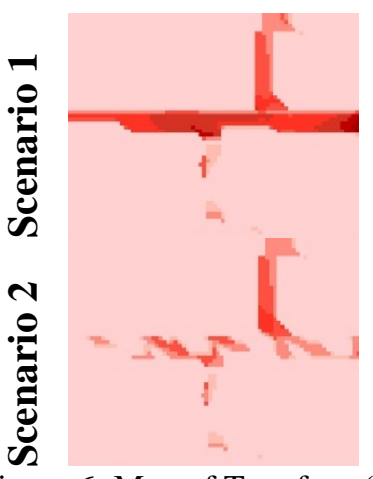

Figure 6: Map of T surface (illustration: Leonardo plugin, 2020).
15:00

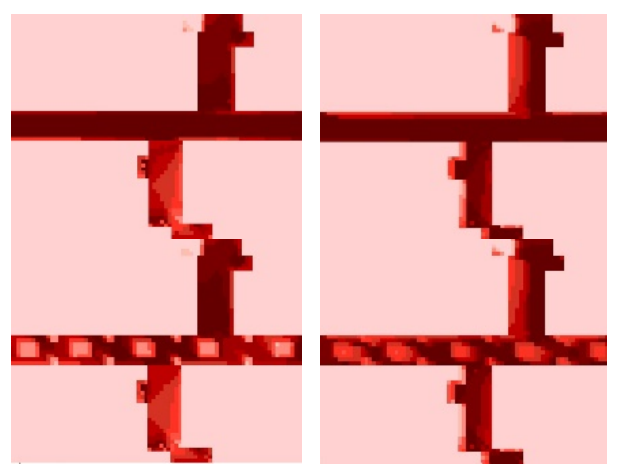

18:00

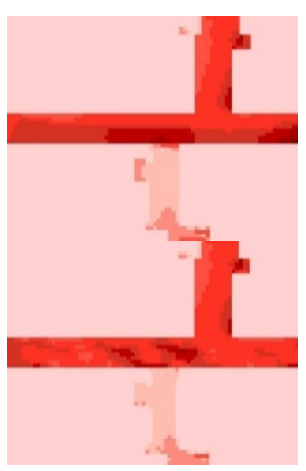

21:00

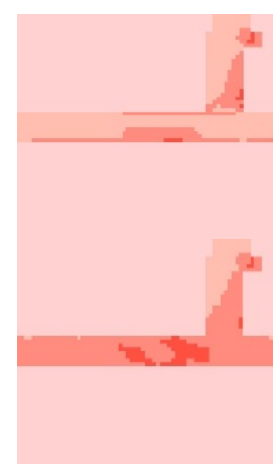

Mean Radiant Temp.

below $22.50{ }^{\circ} \mathrm{C}$ 22.50 to $25.00^{\circ} \mathrm{C}$ 25.00 to $27.50^{\circ} \mathrm{C}$ 27.50 to $30.00^{\circ} \mathrm{C}$ 30.00 to $32.50^{\circ} \mathrm{C}$ 32.50 to $35.00^{\circ} \mathrm{C}$ 35.00 to $37.50^{\circ} \mathrm{C}$ 37.50 to $40.00^{\circ} \mathrm{C}$ 40.00 to $42.50^{\circ} \mathrm{C}$ above $42.50^{\circ} \mathrm{C}$

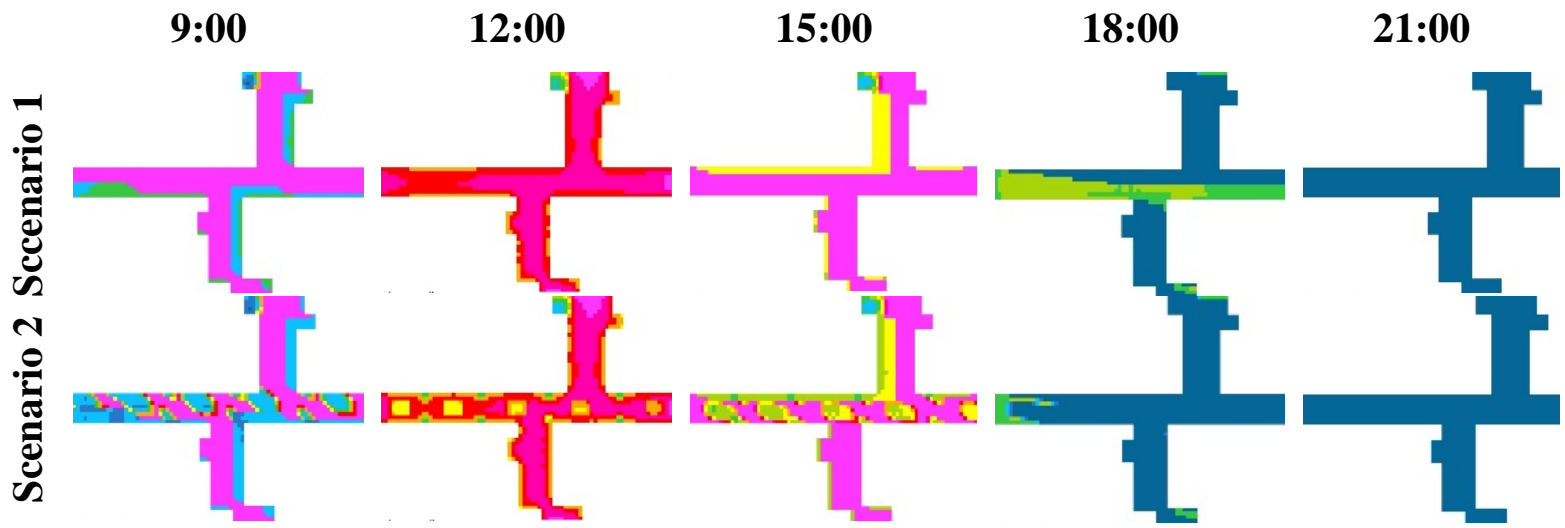

Figure 7: Map of median radiant temperature (illustration: Leonardo plugin, 2020).

In both scenarios, 9:00 coincided with minimum air temperature values $\left(18^{\circ} \mathrm{C}\right)$ and 15:00 with maximum values $\left(25^{\circ} \mathrm{C}\right)$. A $2^{\circ} \mathrm{C}$ air temperature difference was obtained in scenario 1 (without vegetation and with asphalt).

The surface temperature cooled down to $23{ }^{\circ} \mathrm{C}$ was recorded at 12:00 and 15:00 in scenario 2 (with vegetation and granite block pavers), compared to over $29{ }^{\circ} \mathrm{C}$ recorded in scenario 1 
(without vegetation and with asphalt). A $6{ }^{\circ} \mathrm{C}$ difference has thus been observed between the two scenarios.

\subsection{PMV - Scenarios 1 and 2}

The outdoor thermal comfort was determined according to the range of values given to the predicted mean vote (PMV) index by simulation results of ENVI-met. The standard range of thermal perceptions between cold (-3) and hot (3) (Fanger, 1972) was applied to both cases. The results describe the conditions of thermal comfort outdoors, on the street. By looking at the maps, it is possible to identify the most comfortable PMV index at 9:00 for scenario 1 (without vegetation). Comparing both scenarios, the maps show that at 15:00 scenario 2 (with vegetation) has better performance according to the PMV index (comfortable), and the same is true at 12:00. Finally, at 21:00 scenario 2 (with vegetation) reaches slight heat stress in the entire street. The thermal comfort on pedestrian zones is relevant, and evaluation of this performance suggests possible strategies to be applied to improve it.
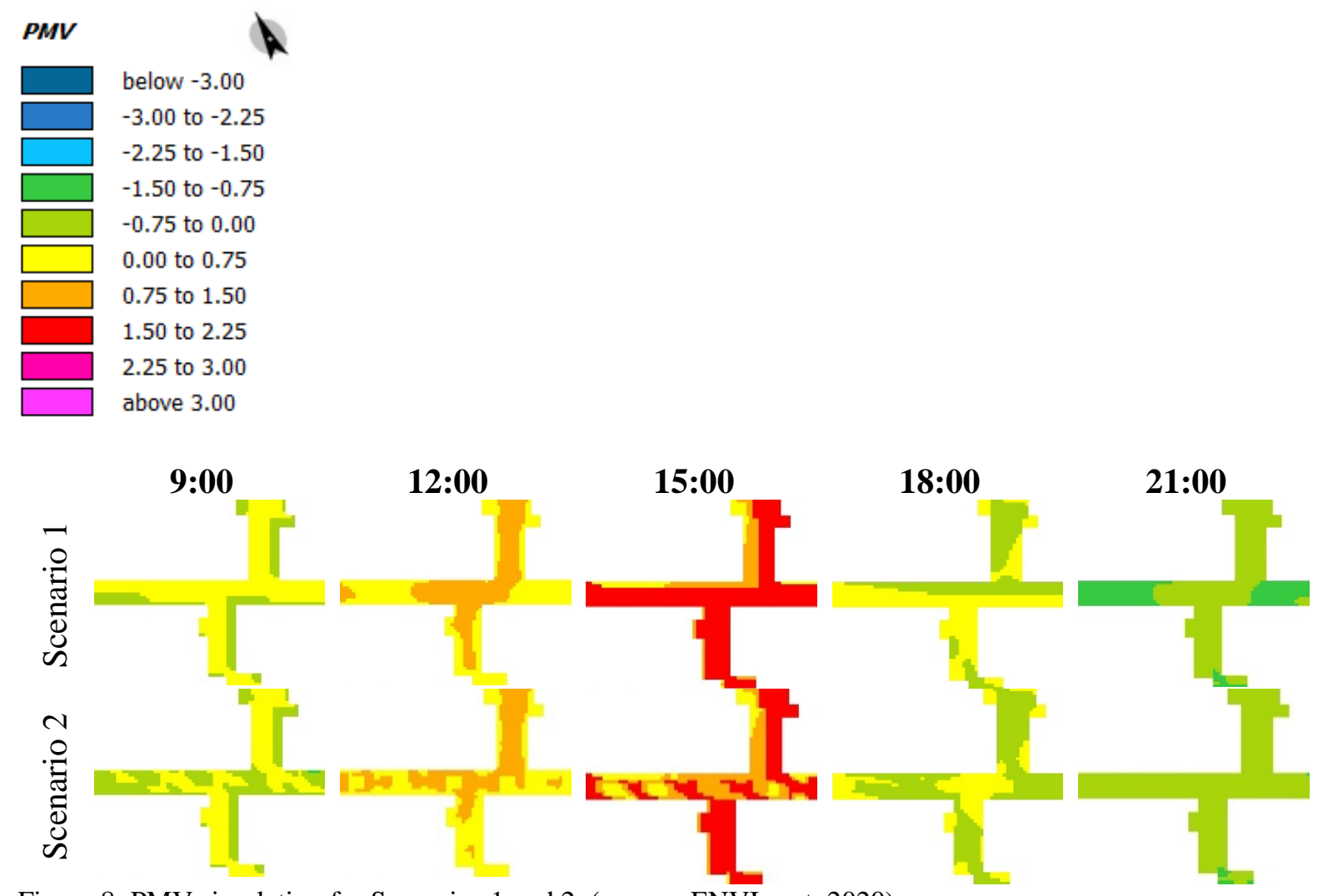

Figure 8: PMV simulation for Scenarios 1 and 2. (source: ENVI-met, 2020).

\section{Discussion}

More pedestrian zones in the city not only contribute to accessibility but also help improve the urban microclimate. The performance of the streets in both scenarios clearly shows the differences; compared with the scenario 1 (with asphalt), scenario 2 reduces the temperature surface by $6{ }^{\circ} \mathrm{C}$ with the help of vegetation and natural materials. Other results regarding median radiant temperature show a difference $\left(12{ }^{\circ} \mathrm{C}\right.$ ) in performance at the same time (at 15:00) in both scenarios. From a theoretical perspective, this phenomenon could be adopted 
throughout the city and promote sustainability with pedestrian zones, key feature of sustainable cities.

This work methodology presents a specific analysis of a single street; adapted to the local context, it could be replicated in other formal scales where pedestrian zones are being planned. It assumes an adequate understanding of each place. In the global context of climate change, outdoor spaces that provide a pleasurable thermal comfort experience for pedestrians effectively improve the quality of urban living. The influence of thermal comfort on outdoor activities is a complex issue comprising both climatic and behavioural aspects (Chen, 2012). The relationship between morphology, climate, and urban landscape is a relationship between aspects that interact in urban spaces and fundamentally determine human activities. Thus, the method used in this research can be applied to any city and translated into a sustainability strategy as the basis for an integrated analysis of urban space.

The PMV results show that at (and before) 9:00 in the morning and at (and after) 21:00 in the evening the index stayed in the comfortable range, having to calculate the peak hours of pedestrian traffic to measure the gauges earlier in the morning and at the sunset. Adopting the best solution suggests incorporating vegetation in order to maintain a constant performance and more hours within the comfortable range of PMV index. The PMV index defines the thermal comfort of a walking person influenced by several environmental parameters (air temperature, mean radiant temperature, relative humidity, air velocity). Thermal comfort is additionally affected by the metabolic rate and clothing insulation (Dyvia \& Arif, 2020). Introduction of pedestrian zones in neighbourhoods would contribute to a decrease in surface temperature and thus to better thermal comfort of pedestrians.

Discussing the results must consider the scale, vegetation and materials, and the method applied in the simulation. Scale of microclimate change: urban microclimate on all kinds of urban scales is fundamentally affected; however, each scale has its own characteristics. This has been validated by the analysis performed on the 15 de Abril Street. In this study of sustainable urban development, the local represented in the scale prevails, the climatic in nature, and the zonal in the representation of the environment; therefore, observing the alterations and effects of the climate on the surface and atmosphere influences the well-being of the people and the preservation of the identity of the place. Vegetation and materials: Werneck \& Romero's study (2018) of the impact of UHI mitigation strategies on the radiant average temperature emphasizes that the characteristics of the finishing materials commonly used on surfaces around buildings should be thought of in order to improve the pedestrians' experience of the thermal environment. In order to obtain a reduction in air temperature, an analysis of negative impacts of the radiation reflected in the TMR to estimate the potential of the mitigation of UHI with cold floors at the microclimate level should be considered.

The impact of vegetation on microclimate results suggests greening could help alleviate the effects of the urban heat island (Yilmaz et al., 2020). Increasing vegetation in cities is therefore one of the key approaches in reducing both air and heat radiations. Cooling benefits of urban vegetation improve environmental temperature, especially in the summer. The effect is local and contributes to improve our sensorial system. A green continuity in the city, including city blocks, creates an ecosystem with multiple benefits, which suggests a number of actions directed towards creation of new centralities (Martínez \& Romero, 2020) and integration of an environmental structure with an urban synergy between nature and society. The re-think on nature-based solutions (NBS) supports a sustainable and resilient urban planning while implementing different ecological concepts: green infrastructure, urban green (and blue) 
spaces, service providing units, service providing elements, sustainable urban drainage systems, and ecosystem-based adaption (Babí et al., 2021). Vegetation should not be confined to parks or green roofs alone. In the streets, attempts should be made to convert the sidewalks into completely pedestrian zones, while urban trees play a vital importance in urban environment and urban landscape, and improve the image of the city by giving it identity. In collaboration with the inhabitants, plans should be made to green the city, choose the appropriate trees, and disseminate the information on incorporating green and civic aspects in building and planning. Through careful planning, use of green building and planning systems and technologies, including green spaces in the built environment, should be encouraged.

Using ENVI-met software: PMV values calculation by Fanger (1972) is very complicated when using manual calculations (Dyvia \& Arif, 2020). Most research and studies on urban microclimate are associated with ENVI-met software. The ENVI-met model analysis was performed on the street level to investigate the thermal comfort effect in addition to configuring climate data and enabling the generation of all simulated data while offering a very simplified modelling platform. Computer simulation of urban microclimates can be used as a research method to understand phenomena related to urban climate and to evaluate mitigation strategies for ICU impacts before their implementation (Werneck \& Romero, 2018). With the simulations, technical information contributes to the diagnosis of the thermal performance of different urban morphologies. According to Silva (2013), the prediction of environmental problems through computer simulations can point out important solutions at low operational cost. For the reliability of the data, however, it is essential that the source of the data is secure and derived from a weather station as close to the study area as possible. The use of computational tools in environmental assessment can assist in decision making, in prognostic studies, and in the construction of a space of higher environmental quality.

\section{Conclusion}

Evaluation of the environmental performance in the urban microclimate on urban roads in the historic centre of the city constitutes an argument for the promotion of urban pedestrianization since the method applied in this work, namely calculating the surface temperature and urban heat islands compared in the two scenarios, highlights the climate effects on local scale. The use of computational simulation provides a tool for urban and spatial analysis that enables the identification and interpretation of the interactions between climate and urban environment. The comparative analysis of the two scenarios, the current situation (scenario 1) and the proposal (scenario 2), considering the variables that affect environmental performance, identifies increased values in land surface temperature and PMV index in public spaces.

In conclusion, scenario 2, which incorporates vegetation and implements natural surface materials, presents a better thermal comfort index while the average radiant temperature performance remains the same. These identified values must be addressed in urban design and planning of cities, essentially with the increase of vegetation and natural surfaces to promote urban adaption to climate change and endorse active mobility with pedestrian zones.

It is recommended that the results of this work be reviewed by urban planners, politicians, and citizens in generalto promote awareness of improvement of urban microclimate. The environmental impact socialized among the actors of society improves the microclimate and consequently the quality of urban life, making neighbourhoods more liveable and efficient by prioritizing pedestrians and bicycles over road traffic. In the future, these city streets could 
constitute a network of pedestrianization which presently seems so necessary to counteract the disorderly urban growth.

\section{María Eugenia Martínez Mansilla, Tarija, Bolivia (me.martinez.mansilla@gmail.com)}

\section{References}

ASHRAE (2001) Standard 55: Thermal comfort condition. American Society of Heating, Refrigerant and AirConditionating Engineers. New York.

Babí, J., Elliot, E., Rugani, B., Philipe, B., Navarrete, T., Sonnemann, G., et al. (2021) Nexus between naturebased solutions, ecosystem services and urban challenges. Land Use Policy, 100, p. 104898.

DOI: 10.1016/j.landusepol.2020.104898

Baptista, G. (2021) Procedimiento de sensoramiento remoto - Land Surface Temperature. Reabilita 10, UNB. Baptista, G. (2003) Ilhas urbanas de calor. Scientific American Brasil, 1(8), pp. 54-59.

Bruse, M., Fleer, H. (1998) Simulating surface-plant-air interactions inside urban environments with a threedimensional numerical model. Environmental Modelling \& Software, 13(3-4), pp.373-384. DOI: $10.1016 /$ S1364-8152(98)00042-5

Bruse, M. (2004) ENVI-met 3.0: Updated Model Overview.

Chen, L., Ng, E. (2012) Outdoor thermal comfort and outdoor activities: A review of research in the past decade. Cities, 29(2), pp. 118-125. DOI: 10.1016/j.cities.2011.08.006

Cheung, T., Schiavon, S., Parkinson, T., Li, P., Brager, G. (2019) Analysis of the accuracy on PMV-PPD model using the ASHRAE Global Thermal Comfort Database II. Building and Environment, 153, pp. 205-217. DOI: 10.1016/j.buildenv.2019.01.055

Dyvia, H. \& Arif, C. (2020) Analysis of thermal comfort with predicted mean vote (PMV) index using artificial neural network. In: IOP Conference Series: Earth and Environmental Sciencies. 622. DOI: $10.1088 / 1755-1315 / 622 / 1 / 012019$

ENVI-met (2020) Start decoding urban nature. Available at: https://www.envi-met.com/ (accessed 16 Nov. 2020).

Fanger, P.O. (1972) Thermal comfort: analysis and applications in environmental engineering. New York, McGraw Hill.

Gehl, J. (2006) The humanization of space: Social life between buildings. Barcelona, Reverté.

Internet 1: https://www.itdp.org/2017/06/23/tod-standard/ (accessed 10 Oct. 2020).

Jacobs, J. (2011) Morte e vida de grandes cidades. São Paolo, Martins Fontes.

Juvančič, M., Žnidaršič, K. (2020) Walkability themes and principles examined on Ljubljana city centre and Južne Fužine neighbourhood. In: Fikfak, A., Nikšič, M., Mady, C., Bizjak, I. \& Blenkuš, M. (eds.) (2020) City Street ${ }^{4}$ Conference. Streets for 2030: Proposing streets for integrated and universal mobility, 23-26 September, pp. 342-361. Ljubljana, University of Ljubljana, Faculty of Architecture, Urban Planning Institute of the Republic of Slovenia.

Lavtižar, K. (2020) Adapting to the urban microclimate - street pollution. In: Fikfak, A., Nikšič, M., Mady, C., Bizjak, I. \& Blenkuš, M. (eds.) (2020) City Street ${ }^{4}$ Conference. Streets for 2030: Proposing streets for integrated and universal mobility, 23-26 September, pp. 298-305. Ljubljana, University of Ljubljana, Faculty of Architecture, Urban Planning Institute of the Republic of Slovenia.

Lombardo, M. (2004) Recent climate change and antropogenic action. São Paulo, Edition Hucitec.

Marrone, P. \& Orsini, F. (2018) Resilienza e ambienti urbani aperti. Misure di adattamento e di mitigazione a confronto. Journal of Technology for Architecture, 15, pp. 348-357. DOI: 10.13128/Techne-22099

Martínez, M. E \& Bustos, M. (2020) New centralities for integrated and universal mobility in Latin America. In: Fikfak, A., Nikšič, M., Mady, C., Bizjak, I. \& Blenkuš, M. (eds.) (2020) City Street ${ }^{4}$ Conference. Streets for 2030: Proposing streets for integrated and universal mobility, 23-26 September, pp. 369-382. Ljubljana, University of Ljubljana, Faculty of Architecture, Urban Planning Institute of the Republic of Slovenia.

Moreno, C., Allam, Z., Chabaud, D., Gall, C. \& Pratlong, F. (2021) Introducing the 15-minute city: Sustainability, resilience and place identity in future post-pandemic cities. Smart Cities , 4(1), pp. 93111. DOI: $10.3390 /$ smartcities4010006

Morin, G., Le Roux, R., Lemasle, P. \& Quénol, H. (2021) Mapping bioclimatic indices by downscalling MODIS land temperature surface: Case study of the Saint-Emilion area. Remote Sensing. 13(1), p. 4. DOI: $10.3390 /$ rs13010004

Oke, T.R. (1987) Boundary layer climates. $2^{\text {nd }}$ edition. Lagos, Methuen Publishers. 
Ottone, M., Cocci, R. \& Marchesani, G. (2020) Massa e leggerezza: qualità urbana lungo le Mura Aureliane a Roma: Walking through walls. TECHNE: Journal of Technology for Architecture \& Environment, 19 pp. 280-289. DOI: 10.13128/techne-7821

Peters, A. (2021) How to transform your street into a 1-minute city. World Changing Ideas. Available at: https://bit.ly/3rOJgx4 (accessed 04 Dec. 2021).

Romero, M., Baptista, G., Lima, E., Werneck, D., Vianna, E. \& Sales, G. (2020) Mudanças climaticas e ilhas de calor urbanas. Brasília, Universidade de Brasília, Facultade de Arquitetura e Urbanismo, ETB. DOI: 10.18830/ISBN.978-85-67405-25-4

Romero, M. (2011) Architecture of place: A bioclimatic vision of sustainability in Brasilia. São Paulo, Nova Técnica Editorial.

Salat, S., Labre, F., Nowacki, C. \& Walker, G. (2011) Cities and forms:On sustainable urbanism. Paris, CSTB Urban Morphology Laboratory, Hermann.

Silva, C. (2013) The thermal comfort of urban canyons: Climate context of the Federal District. Doctoral thesis. Brasília, University of Brasília (UNB), Faculty of Architecture and Urbanism.

Speck, J. (2012) Walkable city. New York, North Point Press.

Stewart, I. \& Oke, T. (2012) Local climate zones for urban temperature studies. Bulletin of the American Metereological Society, 93(12), pp. 1879-1900. DOI: 10.1175/BAMS-D-11-00019.1

SISMET (2004) SENAMHI, Bolivia. Available at: http://senamhi.gob.bo/index.php/sismet (accessed 04 Dec. 2021).

Soelaiman, T. M. A., Soedarsono, W. K. \& Koerniawan, M. D. (2018) The study of thermal comfort in transforming residential area in Bandung using ENVI-met software. Case study: Progo Street. In: The $3^{\text {rd }}$ Habitechno International Conference. pp. 1-10. Available at: https://www.researchgate.net/publication/321713636_The_Study_of_Thermal_Comfort_in_Transformin g_Residential_Area_in_Bandung_using_ENVI-met_Software_Case_Study_Progo_Street (accessed 18 Dec. 2020).

Tumini, I. (2012) El microclima urbano en los espacios abiertos. Estudio de caso en Madrid. Doctoral thesis. Madrid, La Universidad Politécnica de Madrid.

Werneck, D. \& Romero, M. (2018) Análise de microclimas urbanos orientada a mitigação de ilhas de calor em áreas de comércio local do Plano Piloto de Brasília-Brasil. In: 8vo Congresso Luso-Brasileiro para o planejamento urbano, regional, integrado e sustentável (PLURIS 2018). Cidades e territórios Desenvolvimento, atratividade e novos desafios, pp. 675-688. Available at: https://www.researchgate.net/publication/329787934_ANALISE_DE_MICROCLIMAS_URBANOS_O RIENTADA_A_MITIGACAO_DE_ILHAS_DE_CALOR_EM_AREAS_DE_COMERCIO_LOCAL_D O_PLANO_PILOTO_DE_BRASILIA-BRASIL (accessed 20 Feb. 2021)

Yilmaz, S., Mutlu, B., Asku, A., Mutlu, E. \& Qaid, R. (2020) Street design scenarios using vegetation for sustainable thermal comfort in Erzurum, Turkey. Environmental Science and Pollution Research, 28(8), pp.3672-3693. DOI: 10.1007/s11356-020-10555-z 